\title{
Towards a cultural politics of degrowth: prefiguration, popularization and pressure
}

\author{
Miriam Meissner ${ }^{1}$ \\ Maastricht University, The Netherlands
}

\begin{abstract}
This article discusses the role of culture in political ecology, with a focus on degrowth. Environmental scientists increasingly consider systemic societal changes such as degrowth as indispensable for the effective tackling of current climate and ecological crises, while governments and civil society remain skeptical of it. To tackle this challenge, this article argues for the strategic employment of cultural practices, values, narratives and identities within degrowth politics. The majority of existing degrowth scholarship considers cultural politics in terms of prefiguration - the act of performing degrowth futures in the present. Drawing on Stuart Hall's concept of politics as production, Chantal Mouffe's plea for a left populism, John Jordan's practice of artivism and Caroline Levine's notion of strategic formalism, this article advocates an extended understanding of cultural politics. It proposes a conceptual framework and research agenda that considers three dimensions of cultural politics: prefiguration, popularization and pressure. To illustrate these dimensions, it gives examples from contemporary activism and popular culture. The article's scientific goal is to conceptualize the functional and strategic role culture can play as instrument in the campaigning and activist uprising for degrowth. Its practical goal is to offer degrowth advocates and activists insights on how to mobilize various existing and emerging cultural forms towards their end.
\end{abstract}

Keywords: Degrowth, cultural politics, prefiguration, popular culture, activism, Stuart Hall, Chantal Mouffe, John Jordan, Caroline Levine

\section{Résumé}

Cet article traite du rôle de la culture dans le «poltiical ecology», en mettant l'accent sur la décroissance. Les écologistes considèrent de plus en plus les changements sociétaux systémiques tels que la décroissance comme indispensables pour lutter efficacement contre les crises climatiques et écologiques, tandis que les gouvernements et la société civile restent sceptiques à leur égard. Pour relever ce défi, cet article plaide en faveur de l'emploi stratégique des pratiques, valeurs, récits et identités culturels au sein des politiques de décroissance. La majorité des études existantes sur la décroissance considère la politique culturelle en termes de préfiguration - l'acte de réaliser des futurs de décroissance dans le présent. S'appuyant sur le concept de la politique comme production de Stuart Hall, le plaidoyer de Chantal Mouffe pour un populisme de gauche, la pratique de l'artivisme de John Jordan et la notion de formalisme stratégique de Caroline Levine, cet article prône une compréhension élargie de la politique culturelle. Il propose un cadre conceptuel et un programme de recherche qui considère trois dimensions de la politique culturelle: la préfiguration, la vulgarisation et la pression. Pour illustrer ces dimensions, il donne des exemples de l'activisme contemporain et de la culture populaire. L'objectif scientifique de l'article est de conceptualiser le rôle fonctionnel et stratégique que la culture peut jouer comme instrument de campagne et d'activisme pour la décroissance. Son objectif pratique est d'offrir aux défenseurs et aux militants de la décroissance des idées sur la manière de mobiliser diverses formes culturelles existantes et émergentes vers leur fin.

Mots clés: Décroissance, politique culturelle, préfiguration, culture populaire, activisme, Stuart Hall, Chantal Mouffe, John Jordan, Caroline Levine

\footnotetext{
${ }^{1}$ Dr. Miriam Meissner is Assistant Professor at the Faculty for Arts and Social Sciences, Maastricht University, The Netherlands. Email: m.meissner "at" maastrichtuniversity.nl. Acknowledgements: I would like to thank the editors of JPE, two anonymous reviewers, and Federico Savini for their time, insight and constructive comments. This research was supported by the Netherlands Organization for Scientific Research [grant number 016.Veni.195.126].
} 


\section{Resumen}

Este artículo discute, con un enfoque desde el decrecimiento, el papel de la cultura en la ecología política. De manera cada vez más frecuente, los científicos ambientales consideran que los cambios sociales sistémicos, tales como el decrecimiento, son indispensables para el efectivo abordaje de las crisis climáticas y ecológicas, al tiempo que los gobiernos y la sociedad civil se mantienen escépticos. Para enfrentar este reto, este artículo defiende el empleo estratégico de prácticas culturales, valores, narrativas e identidades dentro del aspecto político del decrecimiento. La mayoría de los estudios académicos que se enfocan en el decrecimiento, suelen concebir lo político en la cultura en términos de prefiguración -el acto de interpretar futuros del decrecimiento, en el presente. Con fundamento en la teoría de política como producción, de Stuart Hall; el llamado a un populismo de izquierda, de Chantal Mouffe; la práctica del artivismo, de John Jordan; y la noción de formalismo estratégico de Caroline Levine, este artículo promueve un entendimiento extendido de lo político en la cultura. En el artículo se proponen un marco conceptual y una agenda de investigación que contemplan tres dimensiones de lo político en la cultura: prefiguración, popularización y presión. Para ilustrar estas dimensiones se proporcionan ejemplos de activismo contemporáneo y cultura popular. La meta científica de este artículo, es de conceptualizar el papel funcional y estratégico que la cultura puede jugar como un instrumento de campaña y surgimiento activista en favor del decrecimiento. Por otro lado, la meta práctica es ofrecer a los promotores y activistas del decrecimiento, nociones de cómo movilizar diversas formas culturales, existentes y emergentes, en favor de sus objetivos.

Palabras clave: decrecimiento, lo político en la cultura, prefiguración, cultura popular, activismo, Stuart Hall, Chantal Mouffe, John Jordan, Caroline Levine

\section{Introduction}

This article critically discusses the cultural politics of degrowth. Increasingly, the actors advocating degrowth are not only radical scholars and activists but also natural scientists, who caution that climate change and biodiversity loss are eroding the ecosystem services that humans rely on for survival. Scientists emphasize that "incremental linear changes to the present socio-economic system" will not suffice to curb environmental degradation at the speed and scale required (Steffen et al. 2018: 8257; EAA 2019). Even scientific bodies whose reports predispose a high degree of scientific consensus, such as the Intergovernmental Panel on Climate Change (IPCC), are explicit in their calls for "rapid, far-reaching and unprecedented changes in all aspects of society" (IPCC 2018, n.p.). In contrast, industrialized countries' governments and civil society are reluctant in their pursuit of systemic change. More often than not, calls for systemic change, such as degrowth, are associated with danger and extremism.

Thus, environmental scientists increasingly consider systemic socio-economic transformation as indispensable for the effective tackling of the current climate and ecological crises, while the societal majority of most industrialized countries remains skeptical, if not opposed to widespread transformation. This is also reflected in environmental politics, as most democratically elected representatives continue tackling environmental problems via green growth measures that integrate into, rather than transform, the existing socioeconomic order. The challenge emerging from this mismatch between urgent scientific recommendation on the one hand, and societal inertia on the other, is this: how to gain wider support among civil actors for a degrowth transition, and to resist the opposition of vested interests in maintaining business as usual?

To understand and to confront these challenges, degrowth scholars, advocates and activists take inspiration from a broad variety of social movements and scientific practices, including the work of political ecologists. For this article, the most relevant overlaps between degrowth and political ecology are that they share (1) the transdisciplinary assumption that ecological, economic, political and socio-cultural objects, knowledges, practices and processes mutually define each other; and (2) a political ambition to achieve greater social and ecological justice (Paulson 2015; Robbins 2012). Both communities of practice presume that striving towards greater social justice and ecological regeneration requires systemic societal transformations, which would have to unfold across the overlapping spheres of social institutions, cultural values, productive systems, scientific procedures, biophysical landscapes - and more. Moreover, both communities of practice insist that ecological issues are political in nature. While political ecology has been defined as an "explicit alternative to 'apolitical ecology'" (Robbins 2012: 14), the demand for degrowth is based on the premise that the various ecological crises of our time cannot be tackled effectively within the existing growth-oriented socio-economic 
and ecological order. Therefore, it calls for a societal metabolism that "has a different structure and serves different functions" (D'Alisa et al. 2015: 4). To achieve this transformation, processes of political mobilization and contestation are paramount.

Cultural practice is considered central to this endeavor (Paulson 2017; Latouche 2015). In an effort to advise how degrowth advocacy can learn from political ecology, Paulson has argued that

...one of degrowth's biggest challenges is the narrow cultural scope and shallow historical depth that circumscribe contemporary environmental discourse, constraining our potential to visualize alternatives to currently dominant human-environment relations. (Paulson 2015: 46, emphasis added)

Political ecology has a strong record in critically exploring alternative socio-cultural living arrangements, including livelihoods that do not strive towards ever-increasing economic growth. It can therefore help degrowth scholars and advocates find answers to pressing questions like "How can humans live without the motivation and joys provided by consumer culture?" (Paulson 2015: 47). In considering a historically and geographically broad array of socio-cultural precedents, political ecology can help envision what a future socioculture of degrowth would look like. According to this view, socio-culture inspires degrowth politics. It shows that a degrowth society is possible, and sometimes already in its infancy.

Building on and extending this insight, my goal in this article is to conceptualize the active and versatile role that culture can play in degrowth politics. Specifically, I advocate an understanding of cultural politics that extends notions of culture as a source of experimentation, inspiration and awareness-raising for degrowth. In addition, I define the cultural politics of degrowth as the tactical employment of cultural practices, values, narratives, and identities to pursue a degrowth-oriented transformation of socio-culture and political economy. In addition, I suggest conceptualizing cultural politics on three levels: prefiguration, popularization and pressure. The article's scientific goal is to conceptualize the functional and strategic role culture can play as an instrument in the campaigning and activist uprising for degrowth. A practical goal is to offer degrowth advocates and activists insights for mobilizing present and emerging cultural forms.

The article first introduces degrowth and outlines the ecological motivations for a degrowth transition. It then discusses selected degrowth scholarship on culture and prefiguration. I use Stuart Hall's concept of politics as production, Chantal Mouffe's plea for left populism, John Jordan's practice of artivism, and Caroline Levine's notion of strategic formalism to conceptualize two dimensions of cultural politics that are currently less elaborated in the degrowth literature: popularization and pressure. The article concludes by emphasizing the importance of building strategic cultural alliances and tactics of resistance in degrowth politics.

\section{Why degrowth?}

The concept of degrowth describes a form of political economy, ecology and socio-cultural organization that transcends the imperatives of capital accumulation and growth in Gross Domestic Product (GDP). It refers to productive systems, ideologies and lifeways that define and strive for alternative pathways to wellbeing. For supporters of degrowth, wellbeing would rely less on material affluence and more on values including conviviality and care, providing that basic needs are met (D'Alisa et al. 2015a). While the downscaling of energy and material throughput is key to a degrowth transition, the emphasis of degrowth is on "different, not only on less" (D'Alisa et al. 2015a: 4). "The desired change is qualitative", and "the aggregate result will be degrowth" (ibid: 5). Degrowth is about rethinking the fundamentals of economic practices. Proposed policy measures in this context include:

...resource and $\mathrm{CO}_{2}$ caps; extraction limits; new social security guarantees and work-sharing (reduced work hours); basic income and income caps; consumption and resource taxes with affordability safeguards; support of innovative models of 'local living'; commercial and commerce free zones; new forms of money; high reserve requirements for banks; ethical banking; green investments; cooperative property and cooperative firms. (Kallis et al. 2012: 175) 
This indicates how degrowth is about more than reducing GDP. Instead, it sets out to revise the basic goals, values, motivations, actors, institutions and social relations that structure and give meaning to economic production, consumption and exchange. There are social and environmental reasons why a transition to degrowth is necessary and desirable (Kallis 2015). As these reasons are many, I limit my review to urgent environmental motivations.

Human-induced ecosystem degradation manifests in an overall and accelerating global warming of $1.1^{\circ} \mathrm{C}$ so far, rapid with glacial ice retreat and sea level rise, ocean acidification and more frequent/severe extreme weather events, land degradation and desertification, as well as the mass extinction of plants and animal species - the so-called 'sixth mass extinction' (IPCC 2018; WMO 2019; NASA 2018; UNCCD 2019; WAD 2018; Herring et al. 2018; IPBES 2019b; Ceballos et al. 2017). The interconnected human consequences of these phenomena are illness, starvation and death, economic and non-economic loss, as well as displacement and socio-political instability (DARA 2012; Mukerji 2019; WHO 2009; WMO 2019; Hsiang et al. 2017; Serdeczny et al. 2016; Warner et al. 2013; McAdam 2010; Warner et al. 2009; Buhaug 2016; Sellers et al. 2019; WMO 2020). These are not forecasts: they are happening already.

Scientific prognoses for the future are dire. While the Intergovernmental Panel on Climate Change (IPCC 2018) cautions that limiting global warming to $1.5^{\circ} \mathrm{C}$ would significantly reduce climate-related risks and adaptation needs as compared to more than $2^{\circ} \mathrm{C}$, recent studies suggests that this target is rapidly moving out of reach. Based on a statistical forecasting model that considers global emissions drivers and climate mitigation policies, Raftery et al. assess that the probability of meeting the $1.5^{\circ} \mathrm{C}$ target in this century is currently $1 \%$. "The likely range of global temperature increase is $2.0-4.9^{\circ} \mathrm{C}$, with median $3.2^{\circ} \mathrm{C}$ " (Raftery et al. 2017). Crossing an estimated temperature tipping point between $1{ }^{\circ} \mathrm{C}$ and $2{ }^{\circ} \mathrm{C}$ could in turn set into motion a cascade of interacting bio-geophysical feedbacks (Steffen et al. 2018; Lenton et al. 2019). In combination with human ecosystem degradation (e.g. the human-induced weakening of natural carbon sinks such as forests), these feedbacks could lock the Earth system into an irreversible 'hothouse Earth' pathway - a "rapid pathway toward much hotter conditions... a pathway that could not be reversed, steered, or substantially slowed" (Steffen et al. 2018: 8257). Xu and Ramanathan project that " $4{ }^{\circ} \mathrm{C}$ warming ... would subject $47 \%$ of the land area and almost $74 \%$ of the world population to deadly heat, which could pose existential risks to humans and mammals alike unless massive adaptation measures are implemented" (p. 10319). Notwithstanding the fact that any scientific forecast presupposes a degree of uncertainty, all cited sources assess that it is plausible that the majority of the world population will be subjected to life-threatening levels of warming over the next 80 years, in the absence of more rapid and effective climate change mitigation policies.

Connected to these risks of global heating are the risks of biodiversity loss. The Intergovernmental Science-Policy Platform on Biodiversity and Ecosystem Services (IPBES) cautions that contemporary societies are witnessing species extinction rates unprecedented in human history. Between 1970 and 2016 average population numbers of mammals, birds, fish, reptiles and amphibians around the world declined by 68\% (WWF 2020). One million animal and plant species are now threatened with extinction, many within decades (IPBES 2019a). In destroying the biodiversity that humans rely on for nutrition, clean air and drinking water, medicine et cetera, the IPBES warns, "we" (that is, contemporary societies) "are eroding the very foundations of our economies, livelihoods, food security, health and quality of life worldwide" (IPBES 2019a). Key drivers of biodiversity loss include in descending order: changes in land and sea use, direct exploitation of organisms, climate change, pollution, and invasive alien species. Importantly, the IPBES warns that "negative trends in nature will continue ... in all of the policy scenarios explored in the Report, except those that include transformative change" (IPBES 2019a).

In its recommendations for transformative change, the IPBES recommends the abolishment of "economic incentives" that favor "expanding economic activities" over the "conservation and restoration" of ecosystems (IPBES 2019b: 6) and the "steering away from the current limited paradigm of economic growth" (IPBES 2019a). This insight should not be underestimated. While international sustainability policy currently remains oriented towards green growth, scientists are increasingly united and explicit in arguing that the effective reduction of environmental damage will require an overall reduction of material production and 
consumption, probably leading to stagnating or declining GDP figure. ${ }^{2}$ In July 2019, the European Environmental Bureau released its report Decoupling Debunked, which argues that, while green growth clearly dominated international policy agendas throughout the past decade,

...there is no empirical evidence supporting the existence of a decoupling of economic growth from environmental pressures on anywhere near the scale needed to deal with environmental breakdown, but also, and perhaps more importantly, such decoupling appears unlikely to happen in the future. (Parrique et al. 2019: 3)

Similarly, the European Environmental Agency released a report stating that "Europe will not achieve its sustainability vision of 'living well within the limits of the planet' by continuing to promote economic growth and seeking to manage the environmental and social impacts" (EAA 2019, n.p.).

Given the evident risks that climate change, biodiversity loss and self-reinforcing feedbacks pose to human and non-human species, and considering the mounting scientific consensus on a need for degrowth approaches to tackling these crises, it is important to take the political proposal for a degrowth transition seriously. To that end, it is important to investigate how a degrowth transition can be actively promoted through political campaigning and activism. In this article, I wish to highlight that culture has an active role to play in this. Social movement research emphasizes that culture is more than just a sideshow to political campaigning and activism (Reed. 2019; Engler and Engler 2016; Zhao 2010). From the building of movement identities, to the enactment of protest performances, to media tactics such as culture jamming, culture co-determines when and how social movements arise, how they function internally, and how they impact society (Baumgarten et al. 2014). Given the temporal urgency to halt ongoing processes of global heating and biodiversity loss, my focus in this article is on societal impact. Specifically, I will, in what follows, conceptualize the different levels on which culture can figure as a tool in helping degrowth advocates and activists further their political demands for systemic societal change.

\section{Cultural politics of prefiguration}

Culture already constitutes a key topic in degrowth scholarship. Degrowth scholars tend to agree that a shift in socio-economic institutions must go hand in hand with an overall shift in cultural habits, values and ideologies. Economist and philosopher Latouche, for example, called for a "de-colonization of the imaginary." Drawing on Castoriadis' The imaginary institution for society, he argues that a degrowth transition requires the debunking of established, quasi-religious beliefs in economic progress. It would entail the creation and societal establishment of "different objectives in life" - objectives other than the expansion of production and consumption (Castoriadis 2010, qtd. in Latouche 2015: 117). It would require "profound changes in the psychosocial structure of people in the Western world" (Castoriadis 2010, qtd. in Latouche 2015: 118). This also involves the de-commodification of social relations and the concomitant creation or re-appropriation of the commons (Gómez-Baggethun 2015) - for instance via the establishment of cooperatives (Johanisova et al. 2015). In terms of magnitude, the project is compared to a "cultural revolution" (Latouche 2015: 119) - a "detoxification" that, however, "is not fully possible if a degrowth society has not been already established" (ibid.). This then raises a chicken and egg question: what comes first - a change in culture or a change of socioeconomic institutions?

The answer to this question can only be 'neither nor', as both must go together. This too is addressed in existing degrowth scholarship. Discussing simple living movements, Alexander argues that "[t]he purely macro-economic perspective on degrowth, as a process of planned contraction, fails to highlight the cultural values and practices that must accompany, and perhaps precede, a degrowth transition" (Alexander 2015a: 135). At the same time, he acknowledges that "a simple living movement without a politics would be insufficient to change political and macro-economic structures" (ibid). The reason why culture is relevant to a degrowth

\footnotetext{
2 This is unless a so-called 'New Economy' scenario could be realized, wherein GDP growth would derive predominantly from immaterial production and consumption.
} 
politics is that it can drive degrowth from an embedded bottom-up position. This is important because, as Kallis also concedes, degrowth solutions to existing socio-environmental problems "can never be imposed solely from above ... it has to be part and parcel of an ethico-political project of self-limitation, simplicity and equality to which the members of a collective autonomously subscribe to" (Kallis 2015: 139). The cited degrowth scholarship thus considers changes in culture, such as ethical values and everyday habits, as something beneficial to degrowth politics. What remains largely unspecified, however, is how cultural practice can strategically promote a societal and macro-economic transition to degrowth.

A significant strand of degrowth scholarship suggests that the role of cultural practices and narratives in degrowth politics is to inspire. Prevailing ethics of voluntary simplicity, anti-consumption and frugal living (Alexander and Ussher 2012; Lee et al. 2013), for example, provide an imaginary of what degrowth living would look like. The back-to-the landers provide blueprints for a close-to-nature, ecological way of life (Calvário and Otero 2015). The concept of Buen Vivir ('living well') provides a growth-independent philosophy of wellbeing and development (Gudynas 2015), and there are other examples (Paulson 2017; D'Alisa et al. 2015a). What all of them show is that alternative, degrowth-aligned cultural values, practices and ideologies already exist, and that they are more feasible, happy and socially sustainable than its critics would admit. This might inspire others to follow.

When existing cultural values and practices are viewed as a sources of inspiration for a degrowth transformation, then culture is considered a means of prefiguration. Prefiguration denotes the act of performing in the present what a future degrowth society would be like. Prefiguration also exists in social movements as prefigurative politics. Here, it refers to "the embodiment, within the ongoing political practice of a movement, of those forms of social relations, decision-making, culture, and human experience that are the ultimate goal" (Boggs 1977: 100; Leach 2013). Prefigurative politics implies that a social movement's socio-cultural and political ends are already reflected in its means (Maeckelbergh 2011). In addition, they often combine with practices of experimentation and communication in order to innovate social arrangements and diffuse them (Yates 2015).

Selected examples in existing degrowth scholarship study prefigurative practices in a diverse range of global contexts. The contributors of the special section 'Degrowth: culture, power and change' in the Journal of Political Ecology (edited by Lisa Gezon and Susan Paulson, 2017), for example, examine degrowth-aligned prefiguration in the context of property-making practices among rural squatters in Brazil (DeVore 2017), postdevelopment imaginaries in Peru and the Maldives (Hirsch 2017), resource-saving lifestyle practices in the 'Dancing Rabbit' Ecovillage in Missouri (Lockyer 2017), neo-monasticism among Christian communities in North Carolina (Hall 2017), time-banking practices in New Zealand (McGuirk 2017), 'beautifully poor' urban planning and architecture in Tokyo and Bologna (Le Blanc 2017), and experimental 'design activism' in Helsinki (Berglund 2017), among many other cases. The motivation to engage with, study and communicate such cases is that

... awareness of many possible modes of existence-with myriad sources of richness and pleasure-widens horizons for building unprecedented futures. It does so by liberating us from the fiction that human behaviors currently instrumental to growth are biologically determined universals. (Paulson 2017: 441)

In a socio-historical context where growth habits, values and ideology are mainstream and discursively naturalized, prefiguration can show on a tangible and experience-based level that - to quote a common activist slogan - 'another world is possible', and even desirable.

To that end, prefiguration can also give hands-on insights into the means and scales of resource-use and pollution reduction that degrowth lifestyles make possible. In Degrowth in the suburbs (2019), Sam Alexander and Brendan Gleeson show - in part through auto-ethnographic experiment - how the adoption of specific, often simple habits and techniques can lead to massive reductions in entropy. Entropy is a measure of energy and resource degradation (Ulgiati 2015). Alexander, for example, reports to have reduced electricity consumption in his own household in Melbourne, Australia by $75-80 \%$ per annum via experimental practices 
of sufficiency and retrofitting, practicing an ethics of frugality and making household investments in solar panels and biogas. ${ }^{3}$ The household produced six times more electricity from its solar panels than it consumed, thus providing renewable energy for others as well (Alexander and Gleeson 2019: 120). As a form of prefiguration, the example reveals the enormous extent to which energy demand can be lowered within single households.

Importantly, however, it also demonstrates how certain forms of degrowth-aligned everyday practices are not available to everyone. As the authors admit, "tenure is profoundly important" (Alexander and Gleeson 2019: 114). Household investments in solar panels, for example, rely on the ownership of a house, which tends to be a privilege of the affluent. Schemes to provide solar subsidies to landlords in Melbourne are at an early stage. For degrowth scholarship, it is essential to map such limits and points of exclusion, while, for degrowth politics, it is paramount to overcome them - for instance through practices of sharing and common-ing energy infrastructure. Yet, this is not an argument against prefigurative experiments, or their study and diffusion. Alexander's experiment in sufficiency and retrofitting reveals as much about potential household energy savings as it reveals about present limits in democratizing degrowth-aligned sufficiency habits and techniques.

All of this shows how prefiguration is a central cultural mechanism to research and promote degrowth. In this article however, I wish to argue that culture, if strategically employed, can do more than prefigure degrowth. Because degrowth activism and advocacy can benefit from a tactical vision and employment of culture, it is relevant to purposefully extend the notion of cultural politics for degrowth. To that end, I propose using insights from cultural theorist Stuart Hall. My argument is that Hall's concept of a politics of production can help envision culture's contribution to degrowth politics in a way that includes yet extends prefiguration, and highlights the strategic importance of cultural activity and appropriation within the hegemonic struggle for a degrowth transition.

\section{Cultural politics as a practice of production}

In his work on "the problem of ideology" (1986), Hall discusses the concept of ideology in Marxist thought. He draws on Gramsci to propose an understanding of ideology that, in contrast to classical Marxist philosophy, is not essentially negative - that is assuming a false or distorted relation to reality, which can be countered with a more accurate scientific 'truth.' Instead, Hall presupposes a 'neutral' concept of ideology (Larrain 1991), as a network of ideas, through which "human beings acquire consciousness of reality" and which link "to some class interests or some articulating political principle", such as nationalism or liberalism (Larrain 1991: 8). ${ }^{4}$ Degrowth is such an articulating political principle. Important about Hall's theory is that it understands ideology as something that does not automatically connect to the interests of a given social group (such as labor) or to an articulating political principle (such as degrowth). Instead, Hall maintains that an active and creative process is required, which appropriates and interconnects existing cultural practices (symbolic and embodied), social groups and political principles.

To grasp what this means, it is important to clarify that, for Hall, the 'problem of ideology' is not just theoretical, but focused on politics and strategy. Hall defines ideology as

...the mental frameworks - the languages, the concepts, categories, imagery of thought, and the systems of representation - which different classes and social groups deploy in order to make sense of, define, figure out and render intelligible the way society works. (Hall 1986: 29)

Ideologies "grip the minds of masses and thereby become a 'material force"' (ibid.), which influences how people behave - how they produce, consume, exchange and interact. Ideology tends to fortify established social systems and structures of domination. It makes established institutions, practices and power relations seem natural, desirable and even necessary. Yet, ideological dynamics can also play a role in destabilizing existing orders, and in reinstituting new orders. The political and strategic 'problem of ideology', for Hall, is to find out

3 See the film Sustainable city living on 1/10th of an acre at https://www.youtube.com/watch?v=WeNaMlibiak

${ }^{4}$ Larrain criticizes Hall for misconstruing aspects of Marx's original theory of ideology (Larrain 1991). 
how precisely this process works. In other words, how does ideological struggle unfold, and how does any specific position in this struggle win?

The reason why Hall's theory of ideology is relevant to degrowth politics is that it emphasizes that political interests and ideologies are neither a given, nor built from scratch. Instead, ideologies must be actively assembled from existing social interests and cultural practices. At the time he was writing, Hall was referring the British Left and its response to Thatcherism. He was criticizing the Left for assuming stable class (i.e., labor) interests and identities and therefore failing to engage in an active process of forging new relations. Contemporary degrowth politics can learn from Hall's argument. "To construct a new cultural order", Hall writes, "you need not to reflect an already-formed collective will, but to fashion a new one, to inaugurate a new historic project" (Hall 2017 [1987], n.p.). This means taking stock of existing social forces, movements, conceptions and identities and articulating them into "strategic alliances" (Hall 2017 [1987], n.p.). Based on such alliances, a new articulating principle - such as degrowth - can gain traction, and transition into a cultural hegemony.

To better envision this process, Hall discusses the example of 'democracy.' According to Hall, the concept does not have a totally fixed meaning:

'Democracy' in the discourse of the 'Free West' does not carry the same meaning as it does when we speak of 'popular-democratic' struggle or of deepening the democratic content of political life. We [the Left] cannot allow the term to be wholly expropriated into the discourse of the Right. Instead, we need to develop a strategic contestation around the concept itself. (Hall 1986: 40)

Ideological struggle - in this case between Left and Right - does not necessarily revolve around the truth behind a concept like democracy (i.e. whether or not the concept is accurately applied). Rather, it revolves around conceptual appropriation and interlinking. It means "to detach one meaning of the concept from the domain of public consciousness and supplant it with the logic of another political discourse" (Hall 1986: 41). In relation to degrowth, this could for instance imply detaching the concept of wellbeing from ideas of consumption and GDP growth, and supplanting and it with degrowth ideas of autonomy, conviviality and care. Moreover, ideological struggle for Hall means "articulating this process of ideological de-construction and re-construction to a set of organized political positions, and to a particular set of social forces" (Hall 1986: 41). With regard to degrowth, this could imply connecting degrowth ideas to the interests of labor unions, parents, caregivers, environmental groupings, artists, creatives, and the list goes on. Hall calls this process of appropriating meanings and forging social connections "politics as production" (Hall 2017 [1987], n.p.).

In what follows, I conceptualize two dimensions of politics as production that would complement any prefigurative cultural politics of degrowth. The first, cultural politics of popularization, adopts Hall's plea for appropriating existing cultural values, narratives, practices and identities, and connecting them to an articulating political principle. Specifically, it advocates the expansion of degrowth mobilization into the realm of contemporary popular culture. The second, cultural politics of pressure, relates Hall's plea for the strategic employment of culture in hegemonic struggle to activist direct action for degrowth. Admittedly, this expands Hall's thought on cultural politics into a realm of political practice for which it was not originally intended. Cultural politics as Hall envisions it is about mobilization rather than activism. Arguably, Hall also did not have an urgent ecological crisis in mind when advocating politics as production. Yet, this does not mean that Hall's thought is irrelevant to degrowth activism. On the contrary, I wish to argue that - because of its emphasis on culture as strategic tool - Hall's notion of politics as production can help in envisioning the active role of culture in building political pressure for a rapid degrowth transition.

\section{Cultural politics of popularization}

To further elaborate the notion of a cultural politics of degrowth, it is relevant to first consider in what ways economic growth can be considered as hegemonic today, and how this situation came about. In The hegemony of growth (2016), historian Schmelzer shows how, in the post-World War II era, economic growth transformed into an internationally taken for granted "primary policy goal" (Schmelzer 2015: 264). For the 
Organisation for Economic Co-operation and Development (OECD) member countries, growth became hegemonic in that it allowed political actors of the time to transform international conflicts over resource distribution into techno-managerial debates on increasing GDP (Schmelzer 2015: 266). On a practical level, this implied that "economic growth became ingrained in statistical standards, international policy frameworks, and widely accepted norms" (Schmelzer 2016: 10). Together, these discourses consolidated the view that economic growth was "desirable, imperative, and essentially limitless" (Schmelzer 2015: 264). Focusing instead on the structural function of growth within global capitalism, political scientists Brand and Wissen emphasize that growth provides the material basis to what they conceptualize as the "imperial mode of living" - a mode of production and consumption that is rooted in colonialism and based on the unlimited appropriation of resources, labor capacity and global sinks (Brand and Wissen 2018: 2). While practiced predominantly in the global North, the expenses of this mode of living - labor exploitation and environmental destruction - are borne disproportionately by the global South (Lessenich 2019). Hegemony describes the social forces that strive to normalize this situation, despite its underlying socio-environmental injustices (Brand and Wissen 2018: 15).

Extending these analyses, I wish to underline the vital role of culture, in particular popular culture, in normalizing growth-based imperial modes of living. Popular culture is instrumental in promoting lifestyles that favor the expansion of capitalist production and consumer demand. This is reflected in slogans such as 'shop till you drop' or 'time is money.' It is performed in cultural rituals such as winter holiday shopping or Black Friday (originally the Friday shopping day after Thanksgiving holiday in the US, but now adopted in many other countries). It is promoted via advertisement and time-management literature. It is reproduced in popular cultural literature, films and TV series - from Sex in the City, to Dragon's Den, to Keeping Up with the Kardashians. Beyond that, growth culture is ingrained in everyday organizational culture and philosophy. In contemporary organizations - from hospitals to kindergardens - it is common language to describe a successful practice as 'productive.' Even public organizations, whose primary goal is not to make a profit, consider it selfevident today that they must compete in order to grow. Universities, for instance, seek to grow in terms of student numbers, external funding acquisition, publication output and ratings/reputation. Staying the same or decreasing output or income (e.g. to focus on quality) are not acceptable options. Given this deep and widespread embedding of growth economics in contemporary socio-cultural practice and ideology, the challenge at hand is to transcend growth not only in terms of theory and policy, but also in terms of cultural hegemony. I propose to define this cultural hegemony of growth as the cultural narratives, values, practices and identities that promote ever-increasing material production and consumption, making it seem as if the incessant expansion of economic activity is normal, necessary and even virtuous, while at the same time concealing its massive socio-environmental downsides.

To transform this cultural hegemony, degrowth politics needs to seek alliances that include yet go beyond social groups, movements and interests that are already well-aligned with the degrowth agenda - such as voluntary simplicity, back-to-the landers, Buen Vivir, etc. To clarify, it remains essential that degrowth advocates and activists learn from and seek alliance with prefigurative practices, movements and philosophies. My argument here is that, in addition, an effective cultural politics of degrowth needs to expand its cultural politics from prefiguration into mainstream popular culture. This implies connecting with social forces and appropriating meanings, values and identities that are not perfectly aligned with the degrowth agenda. Hall underlines that

...the whole purpose of what Gramsci called an organic (i.e. historically effective) ideology is that it articulates into a configuration of different subjects, different identities, different projects, different aspirations. It does not reflect, it constructs a 'unity' out of difference. (Hall 2017 [1987], n.p.)

Though seemingly counterintuitive, a "historically effective" ideology is characterized by a certain degree of internal incoherencies. It is "the illusion of the intellectual", Hall writes, "that ideology must be coherent" (ibid.). In this context, politics as production means to appropriate disparate social meanings, values and identities and align them with degrowth as articulating political principle. 
What could this mean in terms of cultural politics of degrowth? Certainly it does not mean that every popular cultural practice, narrative or identity must be aligned with the degrowth agenda. Keeping Up with the Kardashians will probably never become degrowth ideology, nor will Black Friday. Yet, there is a range of practices, narratives and identities in existing popular culture that share key ideas and concerns with degrowth. A good example in this context is the minimalist lifestyle culture. Currently, people who voluntarily practice frugal living, swap and repair clothes, and garden in their backyards are a minority. The societal mainstream tends to consider them at best as idealist - and at worst as cheap 'hippie weirdos.' What is increasingly popular, however, are self-help guides on how to de-clutter your house and agenda, online blogs on 'minimalist lifestyle hacks', YouTube tutorials on how to live zero waste, and the list goes on. I propose the concept of lifestyle minimalism to refer to this vast ensemble of popular cultural practices (see also Rodriguez 2018; Meissner 2019). Yet, what characterizes lifestyle minimalism, and importantly, what distinguishes these minimalist lifestyles from the sufficiency lifestyles that are already mobilized in degrowth scholarship and advocacy?

Lifestyle minimalism shares with sufficiency lifestyles - such as voluntary simplicity, anti-consumption and frugal living - a basic interest in the reduction of wage labor and consumption, and a tendency to endorse alternative living practices and priorities. The advocates and practitioners of minimalist lifestyles tend to lament 'a world of too much' (stress, clutter, distraction, waste) because it damages the environment and - importantly - because it damages individual wellbeing. Likewise, they have in common that they seek to provide organizing patterns for a 'good life of less', such as tidying formulae for clutter-free houses, or decision-making aids to free up busy agendas. The difference I see between lifestyle minimalism and existing sufficiency initiatives is therefore gradual rather than substantial. The most striking difference perhaps is that lifestyle minimalism often appears to tie in perfectly with today's hegemony of growth. The narratives are told and promoted by hip lifestyle gurus, well-marketed business advisors and thriving social media influencers, who advertise minimalism like a new fashion object. Depending on their media format, minimalist narratives tend to have large print runs, powerful distributors (Amazon, Netflix, Spotify, etc.), and large numbers of followers.

To illustrate these claims, I would like to give two examples - the Japanese organizing consultant Marie Kondo and the duo The Minimalists (aka Joshua Fields Millburn and Ryan Nicodemus). Marie Kondo has sold over 10 million copies of her books worldwide. She has a show on Netflix and a store, selling lifestyle gadgets. She also trains and certifies international consultants in her 'KonMari' tidying method. TIME Magazine ranked Kondo among the 100 most influential people of the year in 2015 - next to people such as Barack Obama. Similarly, the duo The Minimalists claim on their website to "help over 20 million people live meaningful lives with less" (The Minimalists, n.d.). Their films Minimalism: a documentary about the important things and Less is Now are available on Netflix; their podcast is on Spotify; and their four books have been translated into a dozen languages. The Minimalists give interviews in prominent media and have been on multiple speaking tours. They have given talks at Harvard Business School, Apple, TEDx and others and can be hired for events, where "they speak about a wide array of topics, from simple living and 'simple work', to health, relationships, writing, publishing, social media, personal growth, and contribution" (The Minimalists, n.d., 'Hire to speak'). What these two examples show is that minimalist lifestyles are not just popular, but that they also sell extremely well. They tune in with growth hegemony, because their proponents have a profit motive and know how to operationalize various marketing tools to that end - from social media to emotive stories.

This has led to a range of criticisms towards minimalist lifestyle culture. Anthropologist Rodriguez considers the "US minimalist movement" as "constituted through emergent forms of capitalist relations, rather than existing outside of them" (Rodriguez 2017: 9). Rodriguez shows how the movement relies on and benefits from global relations of labor exploitation, which it fails to challenge at a systemic level and in a politicized way. The movement, he argues, can represent "little more than a niche market that a relatively small number of defectors have created for themselves to opt out of wage labor" (ibid.). In previous work, I have interpreted minimalist lifestyle culture as a reflection of contemporary post-ecologism, because it sustains simultaneous discourses of radical change and uncompromising defense of consumer capitalism (Meissner 2019; see also Blühdorn and Welsh 2007). My analysis shows how minimalist self-help guides reproduce aspects of capitalist growth ideology. It also reveals how minimalist lifestyle narratives tend to encourage new forms of consumption, individualize problems of excess, and leave unquestioned the capitalist growth economy as a 
systemic cause. In so doing, the narratives foreclose efforts to tackle these problems through collective political engagement for macro-economic change.

Such insights are important. Yet, they do not imply that lifestyle minimalism is useless for degrowth politics. Rather, the cited analyses indicate that there is work to be done by degrowth advocates and activists in appropriating lifestyle minimalism and mobilizing it for degrowth politics. This, Hall would argue, is what politics as production is about - appropriating popular culture and supplanting it with the logic of an alternative political discourse, a discourse of degrowth in this case. As it stands however, critical theory, public discourse and political activism sometimes dismiss cultural practices and initiatives that are not perfectly aligned with a given political principle, such as degrowth.

Lifestyle minimalism has been dismissed not only for failing to explicitly challenge capitalist growth but also for being practiced by the "wrong" social groups, such as the educated middle classes or wealthy elites. Tying in with critical scholarly analyses of minimalist culture, the left-leaning British newspaper The Guardian for example published a range of critical articles and opinion pieces which criticize minimalism for being "another boring product wealthy people can buy" (Fagan 2017) or "just another mode of materialism" (Burkeman 2020). Such critiques have a point. Yet, for degrowth politics, it would be a lost opportunity to let the story end here. Just as Hall writes that the Left cannot allow the term democracy "to be wholly expropriated into the discourse of the Right", degrowth advocates and activists cannot allow minimalism to be expropriated into neoliberal discourses of individual responsibility and conspicuous consumption. Instead, the task at hand for degrowth advocacy is to strategically use lifestyle minimalism's current popularity while at the same time forging connections to important concepts, values and practices of degrowth, for example commoning, care, conviviality and universal basic income (UBI) (D'Alisa et al. 2015a).

What minimalist trends in contemporary popular culture indicate is that there is a considerable group of people in industrialized countries who are - to quote another recent book title in this field - 'longing for less' (Chayka 2020). This is a social group already convinced that ever-increasing consumption does not lead to ever-increasing levels of wellbeing. As Francine Jay puts it in The Joy of Less:

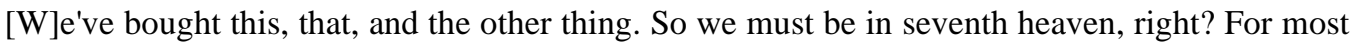
of us, the answer is 'no.' In fact, quite often, the opposite is true: many of these items, and their empty promises, are slowly sucking the money out of our pockets, the magic out of our relationships, and the joy out of our lives. (Jay 2010: 1).

It is also a group that shows basic awareness for the negative social and environmental repercussions of labor, competition, resource exploitation and waste under capitalism. For instance, many minimalist lifestyle authors, influencers and practitioners lament not having enough time for 'the important things', such as care for relatives, meaningful social relations and 'mindful' life experience. Degrowth advocates and activists could appropriate this discourse and relate it to the degrowth principle of care - that is "the daily action performed by human beings for their welfare and for the welfare of their community" (D'Alisa et al. 2015b: 62). Care might also refer to actions for the welfare of the environment and that of other species, such as nature conservation or animal protection. Degrowth emphasizes that - under the right institutional conditions - caring and being cared for generates wellbeing. In so doing, it overlaps with minimalist lifestyle narratives, which tend to conceptualize 'happiness', 'joy' and 'the important things' in similar terms.

\section{Politicizing popular culture}

Currently, the major difference between minimalist and degrowth discourse is that minimalist narratives tend to be framed as individual endeavor (Meissner 2019), while degrowthers emphasize that social relations of care rely on a structural change, a change in socio-economic institutions. Lifestyle minimalists argue that it is up to the individual to set the 'right priorities' (less materialism, more mindfulness, etc.). In contrast, degrowthers emphasize that reducing consumption and wage labor in order to engage in caring activities is currently not an option available to everyone. Instead, it is limited to elites who can afford it. For all others, pressures to make ends meet make it quasi-impossible to dedicate substantial time and energy to caring activities 
(D'Alisa et al. 2015b: 64). To make the engagement in care a practice of wellbeing available to everyone, institutional reforms - such as work sharing (Schor 2015) and a universal basic income (Alexander 2015b) would be needed. Institutional change, however, is subject to democratic struggle and political contestation. By definition, this is a collective endeavor, which minimalist lifestyle discourses - with their emphasis on individual self-optimization - tend to foreclose (Meissner 2019).

The challenge at hand for degrowth advocates and activists, therefore, is to tactically draw upon lifestyle minimalism's current popularity while at the same time seeking to politicize it. Politicization this context, refers to the process of integrating existing minimalist discourses into a structural vision of an institutionalized degrowth future and, importantly, into a political agenda of collective struggle for this future. "The political", Swyngedouw writes, "is the contested public terrain where different imaginings of possible socio-ecological orders compete over the symbolic and material institutionalization of these visions" (Swyngedouw 2015: 90) Existing trends in popular culture - such as lifestyle minimalism, but also mindfulness, zero waste, yoga, and many others - are often aligned with certain aspects of degrowth visions for a possible socio-ecological order. They may not be perfectly aligned. Yet, politics as production means that this is not a reason to dismiss them. On the contrary, dismissing existing trends in everyday and popular culture as incompatible with degrowth would ultimately benefit the ongoing hegemony of capitalist growth in its current neoliberal articulation (selfresponsibility, conspicuous consumption, etc.).

The reason why this neoliberal growth hegemony is and remains culturally powerful is that it allows for a high degree of internal incoherency - to the extent that it is even able to appropriate its counterculture (Fisher 2009). From Che Guevara T-shirts to anti-consumerist philosophy, everything can be marketed. When I buy Henry David Thoreau's Walden and civil disobedience on Amazon, I am fueling economic growth. I might also be asserting my distinctive taste for alternative lifestyles and radical politics, thus engaging in conspicuous consumption. Culturally, this capacity to co-opt almost everything is what makes the current growth hegemony incredibly powerful. Any system that seeks to challenge this hegemony - such as degrowth - will have to find a way of subsuming cultural narratives, practices, values and identities in a way that is equally inclusive (i.e. integrating a wide range of incoherent cultural forms) while at the same time maintaining a basic level of integrity with its articulating political principle and key goals.

For degrowth, these goals include, among others, the decrease of material production and consumption (Lorek 2015), the building of regenerative socio-ecological systems of production (Raworth 2017), and the socially just co-creation, sharing and redistribution of societal wealth in its multiple forms, including time, space, material resources, access to education and healthcare, etc. An effective cultural politics of degrowth would have to produce an alignment with existing popular cultural practices and these goals. It could encourage me to lend Thoreau's Walden and civil disobedience from a community library or to download it from a digital library where it is provided under a creative commons license. Importantly, it would also urge me to get together with others in order to collectively strive for alternative institutions of creative 'commoning' (Bollier and Helfrich 2015) - including institutions through which authors can earn their living without having to enforce artificial scarcity through copyright.

In a second step, any degrowth cultural politics of popularization would also need to accept that some of its cultural features - such as part of its aesthetics - would derive from hip lifestyle influencers and other elite actors. In her work on 'alternative hedonism', philosopher Soper proposes a similar expansion of the scope of anti-consumerist ethics and politics (Soper 2008). Soper acknowledges that from a left-wing point of view this may seem "unorthodox" because the left has "traditionally sought the allegiance of the dispossessed", assuming that this group had the most direct interest in the dismantling of capitalist relations of production (Soper 2018: 572-573). Soper's argument, in contrast, is that it is in the interest of a broader range of social actors to overcome existing relations of production and consumption - and the same applies to degrowth.

The transition to a degrowth society appeals to the interest of a vast array of existing social groups, including the affluent, the dispossessed, and the many that do not fit this binary - such as for instance creative 'flex-workers' (Gill and Pratt 2008; Ross 2009). Degrowth is about distributing wealth in a socially just manner in as much as it is about a building new socio-environmental relationships and so doing, finding new pathways to wellbeing. It therefore concerns and potentially benefits a diverse range of actors, including non-human 
actors. To that end, current scholarship also demands closer attention to the intra-relational dimensions of wellbeing as embedded and embodied practice (Smith and Reid 2018). Accordingly, wellbeing is neither an objective state nor subjective experience, but instead something that emerges through "the dynamic interplay of personal, societal and environmental structures and processes" (White 2017: 133). All of this indicates that any cultural politics of degrowth - if it strives towards becoming hegemonic - needs to actively seek allegiance with an intrinsically diverse multitude of actors and identities.

I would like to clarify that, in advocating popularization, I am not arguing for a degrowth politics that seeks to locate itself at the political center. Rather, I am advocating something that - echoing political philosopher Chantal Mouffe's work on left populism - could be described as the cultural version of a 'degrowth populism.' Key features of this populism are that it systemically opposes the current socio-economic status quo (i.e. growth-oriented capitalism), while at the same time seeking to mobilize and appropriate a diverse array of existing cultural practices, narratives, values and identities towards that end. Importantly, degrowth populism would also seek to appropriate cultural forms that are currently part of and co-opted by the hegemony of neoliberal capitalist growth (such as lifestyle minimalism). Quoting Gramsci and Hall, Mouffe argues that political collectives are not entities that just pre-exist in society. Any populist strategy therefore needs to take an

... anti essentialist approach according to which the 'people' is not an empirical referent but a discursive political construction. It does not exist previously to its performative articulation and cannot be apprehended through sociological categories. (Mouffe 2018: 62)

Mouffe underlines that the target group of any left "discursive political construction" is currently broad, because the number of people negatively affected by neoliberal policies "is much higher than those who are usually considered traditional left voters" (ibid.). This constitutes an opportunity but also a challenge, as it leads to a greater variety and heterogeneity of political demands. These may range from the demands of workers for better pay and social security, to those of minorities for democratic inclusion, to those of creative 'flex-workers' for security of livelihood, and to those of high income elites for 'work-life-balance' - to name just a few.

The challenge for degrowth politics, then, is to include these vastly different demands and identities, uphold their specificities, and at the same time articulate them into a common political project (Mouffe 2018: 63). As it stands, degrowth already proposes institutional reforms that cater for the needs of divergent societal groups and identities. A good example in this context is work-sharing - a degrowth proposal that seeks to "transform underemployment and part-time work into a desirable way of living" (Schor 2015: 195). In combination with the universal basic income, this could benefit both precarious flex-workers and overworked full-time employees, while at the same time solving issues of underemployment that may result from a degrowth-aligned planned economic contraction. ${ }^{5}$ Thus, in terms of institutional politics, degrowth already caters to a variety of societal needs and demands.

In terms of cultural politics, however, degrowth is currently narrower, because it tends to focus on actors and practices of prefiguration. Prefiguration is important in that it tests alternative solutions to societal challenges and because it gives political movements a solid identity. Yet, in This is an uprising, Engler and Engler observe that prefiguration also has its pitfalls:

[O]ne problem is that, if the project of building alternative community totally eclipses attempts to communicate with the wider public and win broad support, it risks a type of self-isolation that limits possibilities for creating social and political change. (Engler and Engler 2016: 274)

\footnotetext{
${ }^{5}$ Unless the end of energy from fossil fuels leads to a significant increase in demand for human labor power (see Sorman 2015).
} 
In order to seriously engage in (and thus win) the hegemonic struggle between growth and degrowth, degrowth advocates need to expand their cultural politics. They need to take stock of existing degrowth-aligned cultural forms and articulate them into strategic alliances with degrowth politics. I conceptualize this process as a cultural politics of popularization.

\section{Cultural politics of pressure}

The first and second dimensions of cultural politics as I have conceptualized it so far focus on using culture to imagine, test and inspire a future degrowth society (prefiguration), and on mobilizing existing cultural practices and identities for a degrowth transition (popularization). The question however remains how actors would - once mobilized - proceed collectively to contest and change existing capitalist growth institutions. As Hall underlines, politics as production "is where forces and relations, in the economy, in society, in culture, have to be actively worked on to produce particular forms of power, forms of domination" (Hall 2017 [1987], n.p.). Echoing Gramsci, Hall's interest in culture is above all strategic. It is about "working on" cultural practice in order to win a given hegemonic struggle. He emphasizes that, in the absence of such strategic cultural activity, "[y]ou lose because you lose because you lose" (ibid.). Building on this understanding of culture as strategic political activity, this last section of the article pursues the question how culture can figure as a means in building political pressure for a degrowth transition. This, admittedly, is a broad question that reaches into social movement studies, transition studies, political philosophy and other fields. To narrow it down, I will focus on cultural practice in direct action and civil disobedience for degrowth.

Direct action and civil disobedience are different from mobilization and campaigning in that their focus is not on persuading actors, such as fellow-citizens or governments, to act in a certain way. Instead, direct action is a practice of resistance to a given process or status quo (e.g., deforestation or economic growth). This resistance can either consist in blocking a process (e.g., by climbing a tree that is about to be cut) or in exerting pressure on actors to behave in a certain way (e.g., by not leaving a place until a demand be fulfilled). Civil disobedience can be defined as "an intentionally unlawful and principled collective act of protest that has the political aim of changing (a set of) laws, policies, or institutions" (Celikates 2015: 130). For both moral and strategic reasons, the practitioners of direct action and civil disobedience tend to adhere to an ethics of nonviolence, which forbids the violation of others' physical integrity as well as other forms of violence (e.g., verbal abuse).

While the exact definitions of direct action, civil disobedience and non-violence remain subject to debate within political philosophy and social movement studies (Celikates 2015), I focus on the role of culture in future direct action for degrowth. To envision what this may entail, it is helpful to cite 'artivist' John Jordan, who draws a relevant distinction between two rationales of art in politics. The first is representational. It is about raising awareness for a problem. The second is "artivism" which, for Jordan, is "definitively not" about:

...making political art, art about an issue, such as a performance about the refugee crisis, or a video about an uprising. It is not about showing new perceptions of the world, but about changing it. Refusing representation, artivism chooses direct action. ... By breathing the spirit of art onto direct action, we can come up with irresistible forms of resistance. If you see a bulldozer cutting down a forest to build a new airport, you don't write a song about it, you put your body in its way (maybe while singing!) ... With artivism, the beautiful and the useful overlap. (Jordan 2016a: 1)

For Jordan, artivism employs art tactically for the achievement of a predetermined goal. It is in this direct and instrumental sense that I conceptualize the third dimension of a degrowth cultural politics. Accordingly, culture functions as a tactical instrument for exerting and/or reinforcing pressure on existing societal institutions with the goal of achieving degrowth reforms.

Yet, why would pressure be necessary? As it stands, powerful interest groups work to maintain and fortify business as usual - the ongoing hegemony of growth - notwithstanding its catastrophic social and environmental impacts. It goes beyond the scope of this article to discuss vested interests and their strategies of influencing governments and the wider public. Instead, I take it for granted that the systemic socio-economic 
transformation that degrowthers demand will encounter substantial political resistance. Even if the degrowth movement manages to mobilize extensive parts of society through popularization, it is safe to assume that it will encounter resistance. How to deal with this resistance, however, is rarely addressed in existing degrowth scholarship. In the volume Degrowth: a vocabulary for a new era (D'Alisa et al. 2015), for example, two of fifty-one entries address practices of direct resistance. One addresses disobedience and the other the Indignados (Occupy). Both, however, do not explicitly discuss culture, even if they comment on selected cultural features within activist practice, such as prefigurative forms of activist self-organization.

This indicates that the role of culture in direct action for degrowth is a underexplored research field at present, which may be due to the fact there is no mass activist uprising for degrowth yet. Degrowth scholars therefore have to analyze and learn from other activist movements, whose actors and goals overlap with degrowth - such as struggles for anti-austerity, alter-globalization and climate justice. Because none of these movements has yet managed to stimulate the kind of substantial system change degrowth would entail (Trainer 2012), studies of culture in degrowth activism also contain an element of speculation. They explore cultural tactics within existing activism in order to find out how and why certain tactics work or not, and how they could be up-scaled in order to achieve larger and systemic goals, which currently seem out of reach. To illustrate this argument, it helps to consider a set of actions Jordan co-designed as member of the artivist collective Liberate Tate.

In 2010, the collective was founded with the self-designated goal of "taking creative disobedience against Tate until it drops its oil company funding" (Liberate Tate, n.d.). Between 2010 and 2016, it held a range of unauthorized artistic performance actions within London's museums, Tate Britain and Tate Modern. In 2016, British Petroleum (BP) ended its Tate sponsorship after twenty-seven years - allegedly due to falling oil prices (Brown 2016). While it is hard to determine to what extent Liberate Tate's actions influenced BP's decision to end its Tate sponsorship, there is a lot to learn from the collective's artivist strategy. Jordan underlines that "creative activism" needs to adhere to key strategic principles - principles "for effective beautiful trouble" in order to "win" (Jordan 2016b). These principles include, among many others: "Know your cultural terrain; Don't dress like a protester; Apply aesthetic discipline always; Escalate strategically; Stay on the edges; Put your target in a decision dilemma; Aim to Win!" (Jordan 2016b). From a cultural politics point of view, what is relevant about these principles is how they strategically merge art and activism's dissimilar logics.

According to Jordan, activists tend to conceive of themselves as running out of time - because people are dying already, because we must not hit climate tipping points, et cetera. As a result, they invest less time and reflection into their art, which results in poor aesthetics, and therefore less success. In contrast, art focuses on the process of reflection and the aesthetic form wherein this process culminates. "As an artist you can spend a year doing a research project and in the end you do a performance of two minutes where you eat a tulip and everyone is happy" (Jordan 2016b). Artivism stipulates the combining of both logics. It takes from art methods of designing well-reflected and aesthetically sophisticated forms, while it takes from activism the method of matching plural actions according to a pre-defined and collective political strategy. Beyond that, it unites both fields of practice under a common key principle: Aim to win.

For Liberate Tate, the combination of art and activism implied the designing all actions in a color scheme. Activists' tools, outfits and even sleeping bags were always black, giving performances a recognizable visual appeal while at the same time making it difficult to dismiss the actions as "mere activist disturbances" - to be removed by police or security as quickly as possible. Liberate Tate "would use the language of art, they used the aesthetics of art, and yet it was activism, they were doing it illegally but it was in the museum" (Jordan 2016b). This then put the Tate into "decision dilemma." "What would the audiences who came to the museum think if suddenly they saw a security guard stopping this beautiful performance happening in an art gallery" (Jordan 2016b). Combined with the activist principles of repeating and strategically escalating actions, Liberate Tate's artistic principles played a key role in building up political pressure.

Degrowth activism can learn from this strategic combination of art and activism. This is not to say that direct action for degrowth must always be artistic. Rather, I suggest that degrowth activism should make strategic use of cultural forms. Cultural form in this context refers to any type of organizing pattern that structures the meaning, perception and performance of activism. In Forms (2015), cultural theorist Caroline 
Levine distinguishes between four key forms governing social life - wholes, rhythms, hierarchies and networks - and argues that the analysis of these forms in their respective societal contexts can produce valuable insights into socio-political institutions and their transformation. To that end, Levine proposes applying the toolkit of formal analysis from art, literary and design studies to a wide array of societal objects and practices.

Activist blockades, for instance, constitute forms. In Levine's terms, they could be described as wholes - as bounded enclosures that have a range of politically relevant affordances. The concept of affordance describes actions and perceptions latent in forms - ready to become actualized. Levine underlines that wholes "do not afford only imprisonment, exclusion and the quelling of difference; they also afford centrality and inclusiveness" (Levine 2015: 39). This also applies to road blockades, which tend to exclude non-activists, while at the same time affording centrality to what is happening within the blockade (e.g. speeches and performances) and reinforcing solidarity among the activists involved. Tactically, this is a relevant insight.

Any tactical cultural politics of degrowth would apply and combine forms in a savvy and goal-oriented manner. If the goal is to resist a certain process while at the same time gaining attention and establishing group spirit, then a blockade is appropriate. If the goal is to foster interaction between activists and the wider public, then other forms - such as participatory art - may be better suited. A cultural politics of pressure stipulates the purposeful combination of cultural forms for the direct pursuit of a predetermined goal. For degrowthers, this goal is a systemic transformation of society and the political economy towards new values, goals and institutions of production and exchange.

Keeping this goal in mind opens up a range of pathways for direct action. Activist blockades and disobedient performances directly relate to the goal of resisting 'business as usual' - the institutions of growth. Yet, there are many additional pathways that direct action for degrowth could take. For example, it could propagate alternative values and desires. While this may appear to be a form of prefiguration, it is worth highlighting that direct action can also target consumer capitalism's desiring machine (Deleuze and Guattari 2009 [1972]) - for instance through 'culture jamming.' The website Beautiful Rising, which presents and evaluates a collection of activist tactics, describes culture jamming as "semiotic jiu-jitsu and creative disruption ... subversive and marginalized ideas can spread contagiously by reappropriating artifacts drawn from popular media and injecting them with radical connotations" (n.d.).

For example, in 2019, the German climate action alliance Ende Gelände launched an adbusting campaign featuring photographs of well-known national politicians. One of the posters shows Wolfgang Schäuble - the current President of the German Parliament and member of the conservative party CDU. His photograph is framed by the sentence "As much as we have to fight hunger, we should limit economic growth", printed in quotation marks. Underneath the image, the footer displays a logo titled "Federal Ministry of System Change and Coal Exit", which mimics the design of German ministerial logos - a strip in national ensign colors with the federal eagle on its left. In place of the federal eagle, however, the logo shows the Ende Gelände icon featuring two coal pickaxes forming a cross (Figure 1). The poster thus combines signifiers of mainstream politics and administration with a degrowth message. Via connotation, the composition performs in public space what it would be like if de-growing was a taken for granted collective ambition - pursued by mainstream politicians and national ministries - just as growth is, at present. It directly targets the political actors and public discourses that currently maintain growth hegemony.

An action performed by the socio-environmental movement Extinction Rebellion Netherlands shows how culture jamming can also target the embodied rituals of consumer capitalism. On Black Friday 2019, XR NL organized artistic fashion shows right in front of two big shopping centers in Amsterdam and Utrecht. The shows included pink carpets as catwalks and models wearing garments made of re-used and up-cycled materials, such as clothes, curtains and fishing nets. Some of these creations alluded to ecological problems such as overfishing, plastic pollution and species extinction. Most garments had been created in collective mending workshops by the subgroup XR Fashion Action, which has the slogan "reduce, reuse, refuse - rewear, repair, rebel." The action combined education about fast fashion's impact on the environment with artistic performance and audience participation. It featured music attracting passers-by and invited the audience to dance along with the performers (after the official catwalk performance). The reason why the action is relevant for degrowth activism is that it gives an idea of what a direct action for anti-consumerism and sufficiency lifestyles might 
look like. It not only disrupted Black Friday shopping with an environmental message but also appropriated a well-known ritual of the fashion industry - the fashion show - to showcase alternative practices of clothing and self-expression.
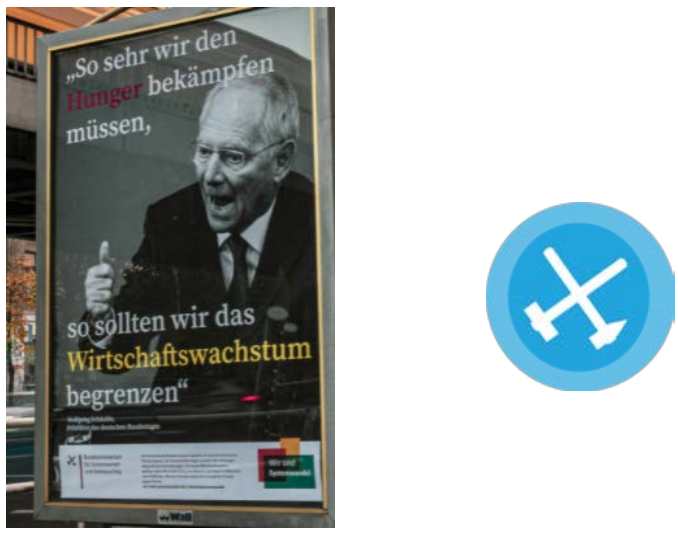

Figure 1: Ende Gelände adbusting campaign, 2019 and logo. Source: https://twitter.com/Ende_Gelaende/status/1195297824449150976

Following and extending XR's example, degrowth activists can use tactics of art, design, and performance in order to disrupt business as usual while at the same time promoting alternative values for wellbeing, such as simplicity and conviviality. What if degrowth activists tapped into and repurposed the aesthetics of lifestyle minimalism for degrowth activism? What if they used images of charming clutter-free homes in order to adbust Black Friday advertising, while at the same time endorsing the degrowth values of simplicity and sufficiency? What if degrowth activist appropriated Marie Kondo's tidying formulae in order to organize convivial workshops for de-cluttering and sharing or redistributing material wealth? In this way, cultural politics of prefiguration, popularization and pressure would - to different degrees - coincide.

Obviously, my suggestions are speculative. The effects of different tactics would have to be tested and researched further. Moreover, critical studies would have to question actions in light of potential unintended side effects, such as excluding different actors and/or demographics. Yet, what the examples show is that cultural forms can take center stage in political activism. They constitute key factors determining the success of any future mobilization and direct action for degrowth.

\section{Conclusion: producing alliances, resisting hegemony}

Reflecting on degrowth artivism, Jordan has argued that it would benefit the degrowth movement to adopt a politicized understanding of cultural practice. His criticism is that

...many in the transition town networks - or in other cultures of ecological alternatives such as permaculture et al. - while thinking long term solutions and material infrastructures, seem to think that our culture will be able to magically transition from capitalism to "something nicer, greener, etc." without resistance. I don't believe this culture will somehow undergo a voluntary transformation to a sane, equitable and sustainable way of living. (Jordan 2016a: 7)

In response to this argument, this article recommends that degrowth scholarship extends its consideration of cultural politics. As Hall shows, cultural hegemonies do not change automatically just because a good alternative is in place (which I believe degrowth is). Instead, a more active and strategic process of politics as 
production is required, which takes stock of existing social forces, movements, conceptions and identities and articulates them into strategic alliances.

On the one hand, this involves a process of popularization. Degrowthers need to mobilize practices and identities in contemporary popular culture, and connect them to the political project of degrowth - even if this means a loss in internal coherency. On the other hand, degrowthers need to consider the tactical deployment of cultural forms in direct action campaigns for degrowth. Forming strategic alliances implicates that degrowthers partner with actors and movements whose values and goals overlap, such as climate justice or lifestyle minimalism. In so doing, a degrowth-oriented 'movement of movements' can be built. Ideally, this movement of movements would become strong enough to not only build alternatives but also collectively resist the current powers that seek to perpetuate capitalist growth hegemony.

Only by practicing cultural politics across the dimensions of prefiguration, popularization and pressure will it be possible the to achieve a substantial transformation of cultural hegemony while at the same time resisting vested interests in their efforts to maintain 'business as usual.' By practicing cultural politics as production and resistance, the degrowth movement will potentially stand a chance in achieving the rapid and systemic socio-economic change scientists deem indispensable for the effective tackling of the current climate and ecological crises, while at the same time creating just and convivial common futures.

\section{References}

Alexander, S. 2015a. Simplicity. In D'Alisa, G., F. Demaria and G. Kallis (eds.). Degrowth: a vocabulary for a new era. London: Routledge. Pp. 133-137.

Alexander, S. 2015b. Basic and maximum income. In D'Alisa, G., F. Demaria and G. Kallis (eds.). Degrowth: a vocabulary for a new era. London: Routledge. Pp. 146-149.

Alexander, S. and B. Gleeson. 2019. Degrowth in the suburbs: a radical urban imaginary. Singapore: Palgrave.

Alexander, S. and S. Ussher. 2012. The voluntary simplicity movement: a multi-national survey analysis in theoretical context. Journal of Consumer Culture 12(1): 66-86.

Baumgarten, B., P. Daphi and P. Ullrich. 2014. Protest and culture: Concepts and approaches in social movement research - an introduction. In Baumgarten, B., P. Daphi and P. Ullrich (eds.). Conceptualizing culture in social movement research. London: Palgrave. Pp. 1-19.

Beautiful Rising. n.d. Culture jamming. https://beautifulrising.org/tool/culture-jamming

Berglund, E. 2017. Steering clear of politics: local virtues in Helsinki's design activism. Journal of Political Ecology 24(1): 566-581.

Blühdorn, I., and I. Welsh. 2007. Eco-politics beyond the paradigm of sustainability: a conceptual framework and research agenda. Environmental Politics 16(2): 185-205.

Boggs, C. 1977. Marxism, prefigurative communism and the problem of workers' control. Radical America 6: 99-122.

Bollier, D., and S. Helfrich (eds.). 2015. Patterns of commoning. Amherst: Levellers Press.

Brand, U. and M. Wissen. 2018. The limits to capitalist nature: theorizing and overcoming the imperial mode of living. London: Rowman \& Littlefield.

Brown, J.M. 2016. BP ends 27-year sponsorship of Tate as falling oil price takes toll. Financial Times, 11 March. https://www.ft.com/content/fc89bc54-e78f-11e5-bc31-138df2ae9ee6

Buhaug, H. 2016. Climate change and conflict: taking stock. Peace Economics, Peace Science and Public Policy 22(4): 331-338.

Burkeman, O. 2020. First Kondo, now cosy: but do you have to buy into lifestyle trends? The Guardian, 31 Jan. https://www.theguardian.com/lifeandstyle/2020/jan/31/first-kondo-now-cosy-but-do-you-have-tobuy-into-lifestyle-trends

Calvário, R. and I. Otero. 2015. Back-to-the-landers. In D'Alisa, G., F. Demaria and G. Kallis (eds.). Degrowth: a vocabulary for a new era. London: Routledge. Pp. 142-145.

Castoriadis, C. 1997. The imaginary institution of society. Cambridge: MIT Press. 
Ceballos, G., P.R. Ehrlich and R. Dirzo. 2017. Biological annihilation via the ongoing sixth mass extinction signaled by vertebrate population losses and declines. Proceedings of the National Academy of Sciences 114(30): E6089-E6096.

Celikates, R. 2015. Civil disobedience. In Mazzoleni G., K. Barnhurst, K. Ikeda, M. Rousiley and H. Wessler (eds.). The international encyclopedia of political communication. Sussex: Wiley-Blackwell. Pp. 128133.

Chayka, K. 2020. The longing for less: living with minimalism. London: Bloomsbury.

DARA. 2012. Climate Vulnerability Monitor. $2^{\text {nd }}$ ed. Report by the Development Assistance Research Associates (DARA) and the Climate Vulnerable Forum. https://daraint.org/wpcontent/uploads/2012/10/CVM2-Low.pdf

D'Alisa, G., F. Demaria and G. Kallis (eds.). 2015a. Degrowth: a vocabulary for a new era. London: Routledge.

D'Alisa, G., M. Deriu and F. Demaria. 2015b. Care. In D'Alisa, G., F. Demaria and G. Kallis (eds.). Degrowth: a vocabulary for a new era. London: Routledge. Pp. 63-67.

Deleuze, G. and F. Guattari. 2009 [1972]. Anti-Oedipus: capitalism and schizophrenia. London: Penguin.

DeVore, J. 2017. Trees and springs as social property: a perspective on degrowth and redistributive democracy from a Brazilian squatter community. Journal of Political Ecology 24(1): 644-666.

EAA. 2019. Europe's State of the Environment 2020: change of direction urgently needed to face climate change challenges, reverse degradation and ensure future prosperity. Press release, 4 Dec. https:/www.eea.europa.eu/highlights/soer2020-europes-environment-state-and-outlook-report

Engler, M. and P. Engler. 2016. This is an uprising: how nonviolent revolt is shaping the twenty-first century. New York: Nation Books.

Fagan, C. 2017. Minimalism: another boring product wealthy people can buy. The Guardian, 4 March. https:/www.theguardian.com/lifeandstyle/2017/mar/04/minimalism-conspicuous-consumptionclass?CMP=fb_gu

Fisher, M. 2009. Capitalist realism: is there no alternative? Ropley: Zero Books.

Gill, R., and A. Pratt. 2008. In the social factory? Immaterial labour, precariousness and cultural work. Theory, Culture and Society 25(7-8): 1-30.

Gómez-Baggethun, E. 2015 Commodification. In D'Alisa, G., F. Demaria and G. Kallis (eds.). Degrowth: a vocabulary for a new era. London: Routledge, Pp. 67-71.

Gudynas, E. 2015. Buen vivir. In D'Alisa, G., F. Demaria and G. Kallis (eds.). Degrowth: a vocabulary for a new era. London: Routledge. Pp. 201-204.

Hall, A.C. 2017. Neo-monastics in North Carolina, degrowth and a theology of enough. Journal of Political Ecology 24(1): 543-565.

Hall, S. 2017 [1987]. Gramsci and us. Verso Blog, 10 Feb. https://www.versobooks.com/blogs/2448-stuart-hallgramsci-and-us

Hall, S. 1986. The problem of ideology: Marxism without guarantees. The Journal of Communication Inquiry 10(2): 28-44. See also

Herring, S.C., N. Christidis, A. Hoell, J.P. Kossin, C.J. Schreck and P.A. Stott (eds.). 2018. Explaining extreme events of 2016 from a climate perspective. Bulletin of the American Meteorological Society 99(1). http://www.ametsoc.net/eee/2016/toc_abstract.pdf

Hirsch, E. 2017. The unit of resilience: unbeckoned degrowth and the politics of (post) development in Peru and the Maldives. Journal of Political Ecology 24(1): 462-475.

Hsiang, S., R. Kopp, A. Jina, J. Rising, M. Delgado, S. Mohan, D.J. Rasmussen, R. Muir-Wood, P. Wilson, M. Oppenheimer, K. Larsen and T. Houser. 2017. Estimating economic damage from climate change in the United States. Science 356(6345): 1362-1369.

IPBES. 2019a. Nature's dangerous decline 'unprecedented': species extinction rates 'accelerating.' Press release by the Intergovernmental Panel on Biodiversity and Ecosystem Services. https://ipbes.net/news/MediaRelease-Global-\%20Assessment 
IPBES. 2019b. Summary for policymakers of the global assessment report on biodiversity and ecosystem services of the Intergovernmental Science-Policy Platform on Biodiversity and Ecosystem Services. https://ipbes.net/global-assessment

IPCC. 2018. Summary for policymakers of IPCC Special Report on global warming of $1.5^{\circ} \mathrm{C}$ approved by governments, press release by the Intergovernmental Panel on Climate Change (IPCC). https://www.ipcc.ch/2018/10/08/summary-for-policymakers-of-ipcc-special-report-on-globalwarming-of-1-5c-approved-by-governments/

Jay, F. 2010. The joy of less: a minimalist living guide. How to declutter, organize, and simplify your life. Medford: Anja Press.

Johanisova, N., P. Surinach and P. Philippa. 2015. Co-operatives. In D'Alisa, G., F. Demaria and G. Kallis (eds.). Degrowth: A vocabulary for a new era. London: Routledge, Pp. 152-156.

Jordan 2016a. Artivism: injecting imagination into degrowth. Degrowth in Bewegung(en). https://www.degrowth.info/wp-content/uploads/2016/07/DIM_Artivism.pdf

Jordan 2016b. On creative activism. Presentation at the Fossil Free Culture NL launch event, Amsterdam, 6 April. https://www.youtube.com/watch?v=WPQ2MyLwiJI

Kallis, G. 2015. Social limits of growth. In D'Alisa, G., F. Demaria and G. Kallis (eds.). Degrowth: a vocabulary for a new era. London: Routledge, Pp. 137-140.

Kallis, G., C. Kerschner and J. Martinez-Alier. 2012. The economics of degrowth. Ecological Economics 84: 172-180.

Larrain, J. 1991. Stuart Hall and the Marxist concept of ideology. Theory, Culture and Society 8(4): 1-28.

Latouche, S. 2015. Imaginary, decolonization of. In D'Alisa, G., F. Demaria and G. Kallis (eds.). Degrowth: a vocabulary for a new era. London: Routledge. Pp. 177-120.

Leach, D. 2013. Prefigurative politics. In Snow, D.A., D. della Porta, B. Klandermans and D. McAdam (eds.). The Wiley-Blackwell encyclopedia of social and political movements. Oxford: Blackwell. Pp. 1004-1006.

LeBlanc, R. M. 2017. Designing a beautifully poor public: postgrowth community in Italy and Japan. Journal of Political Ecology 24(1): 449-461.

Lee, M. S., H. Cherrier and R. Belk. 2013. Journal of Macromarketing special issue: anti-consumption research and society. Journal of Macromarketing 33(3): 187-189.

Lenton, T. M., J. Rockström, O. Gaffney, S. Rahmstorf, K. Richardson, W. Steffen and H.J. Schellnhuber. 2019. Climate tipping points-too risky to bet against. Nature 575: 592-95.

Levine, C. 2015. Forms: whole, rhythm, hierarchy, network. Princeton: Princeton University Press.

Liberate Tate. n.d. Liberating Tate. http://www.liberatetate.org.uk/liberating-tate/

Lockyer, J. 2017. Community, commons, and degrowth at Dancing Rabbit Ecovillage. Journal of Political Ecology 24(1): 519-542.

Lorek, S. 2015. Dematerialization. In D'Alisa, G., F. Demaria and G. Kallis (eds.). Degrowth: a vocabulary for a new era. London: Routledge. Pp. 83-86.

Maeckelbergh, M. 2011. Doing is believing: prefiguration as strategic practice in the alterglobalization movement. Social Movement Studies 10(1): 1-20.

McAdam, J., ed. 2010. Climate change and displacement: multidisciplinary perspectives. Oxford: Hart Publishing.

McGuirk, E. 2017. Timebanking in New Zealand as a prefigurative strategy within a wider degrowth movement. Journal of Political Ecology 24(1): 595-609.

Meissner, M. 2019. Against accumulation: lifestyle minimalism, degrowth and the present post-ecological condition. Journal of Cultural Economy 12(3): 185-200.

Mouffe, C. 2018. For a left populism. London: Verso.

Mukerji, R. 2019. Climate change and hunger. Report for the Global Hunger Index 2019. https://www.globalhungerindex.org/issues-in-focus/2019.html 
NASA. 2018. Ramp-Up in Antarctic ice loss speeds sea level rise. News release by the Jet Propulsion Laboratory, California Institute of Technology, 13 June. https://www.jpl.nasa.gov/news/news.php?feature=7159

Parrique T., J. Barth, F. Briens, C. Kerschner, A. Kraus-Polk, A. Kuokkanen and J.H. Spangenberg. 2019. Decoupling debunked: evidence and arguments against green growth as a sole strategy for sustainability. Report by the European Environmental Bureau. https://eeb.org/library/decouplingdebunked/

Paulson, S. 2017. Degrowth: culture, power and change. Journal of Political Ecology 24(1): 425-448.

Paulson, S. 2015. Political ecology. In D'Alisa, G., F. Demaria and G. Kallis (eds.). Degrowth: a vocabulary for a new era. London: Routledge. Pp. 45-49.

Raftery, A.E., A. Zimmer, D.M. Frierson, R. Startz and P. Liu. 2017. Less than 2 C warming by 2100 unlikely. Nature Climate Change 7(9): 637-641.

Raworth, K. 2017. Doughnut economics: seven ways to think like a 21st-century economist. London: Penguin.

Reed, T.V. 2019. The art of protest: culture and activism from the Civil Rights Movement to the present. Minneapolis, MN: University of Minnesota Press.

Robbins, P. 2012. Political ecology: a critical introduction. Oxford: Wiley-Blackwell.

Ross, A. 2009. Nice work if you can get it: life and labor in precarious times. New York: NYU Press.

Schmelzer, M. 2015. The growth paradigm: history, hegemony, and the contested making of economic growthmanship. Ecological Economics 118: 262-271.

Schmelzer, M. 2016. The hegemony of growth: the OECD and the making of the economic growth paradigm. Cambridge: Cambridge University Press.

Schor, J.B. 2015. Work sharing. In D'Alisa, G., F. Demaria and G. Kallis (eds.). Degrowth: a vocabulary for a new era. London: Routledge. Pp. 195-197.

Sellers, S., K.L. Ebi and J. Hess. 2019. Climate change, human health, and social stability: addressing interlinkages. Environmental Health Perspectives 127(04): 045002.

Serdeczny, O., E. Waters and S. Chan. 2016. Non-economic loss and damage in the context of climate change: understanding the challenges. Discussion Paper. German Development Institute. https://www.diegdi.de/uploads/media/DP 3.2016.pdf

Smith, T. S. and L. Reid. 2018. Which 'being' in wellbeing? Ontology, wellness and the geographies of happiness. Progress in Human Geography 42(6): 807-829.

Soper, K. 2008. Alternative hedonism, cultural theory and the role of aesthetic revisioning. Cultural Studies 22 (5): 567-587.

Sorman, A. 2015. Societal metabolism. In D'Alisa, G., F. Demaria and G. Kallis (eds.). Degrowth: a vocabulary for a new era. London: Routledge, Pp. 41-45.

Steffen, W., J. Rockström, K. Richardson, T.M. Lenton, C. Folke, D. Liverman, ... and J.F. Donges. 2018. Trajectories of the Earth system in the Anthropocene. Proceedings of the National Academy of Sciences 115(33): 8252-8259.

Swyngedouw, E. 2015. Depoliticization ('the political'). In D'Alisa, G., F. Demaria and G. Kallis (eds.). Degrowth: a vocabulary for a new era. London: Routledge, Pp. 90-94.

The Minimalists. n.d. The Minimalists. https://www.theminimalists.com/

The Minimalists. n.d. Hire the minimalists to speak. The Minimalists. https://www.theminimalists.com/speaking/

Thoreau, H.D. 2004. Walden and civil disobedience. New York: Pocket Books.

Trainer, T. 2012. Degrowth: do you realise what it means? Futures 44(6): 590-599.

Ulgati, S. 2015. Entropy. In D'Alisa, G., F. Demaria and G. Kallis (eds.). Degrowth: a vocabulary for a new era. London: Routledge. Pp. 97-99. 
UNCCD. 2019. Land in numbers. Report by the United Nations Convention to Combat Desertification. https://www.unccd.int/publications/land-numbers-2019-risks-and-opportunities

WAD. 2018. World Atlas of Desertification 3. https://wad.jrc.ec.europa.eu/introduction

Warner, K., C. Ehrhart, A.D. Sherbinin, S. Adamo and T. Chai-Onn. 2009. In search of shelter: mapping the effects of climate change on human migration and displacement. Paper submitted to the UNFCCC. https://unfccc.int/resource/docs/2009/smsn/igo/056.pdf

Warner, K., K. van der Geest and S. Kreft. 2013. Pushed to the limit: evidence of climate change-related loss and damage when people face constraints and limits to adaptation. Report by the United Nations University Institute of Environment and Human Security (UNU-EHS). https://collections.unu.edu/eserv/UNU:1849/pdf11486.pdf

White S.C. 2017. Relational wellbeing: re-centering the politics of happiness, policy and the self. Policy and Politics 45(2): 121-136.

WHO. 2009. Global health risks: mortality and burden of disease attributable to selected major risks. Report by the Horld Health Organization. http://www.who.int/healthinfo/global_burden_disease/GlobalHealthRisks_report_full.pdf

WMO. 2020. WMO Statement on the state of the global climate in 2019. Report by the World Meteorological Organization. https://library.wmo.int/doc_num.php?explnum_id=10211

WMO. 2019. The global climate in 2015-2019. Report by the World Meteorological Organization. https://library.wmo.int/index.php?lvl=notice_displayandid=21522\#.XdaUir97lsM

WWF. 2020. Living Planet Report 2020: Bending the curve of biodiversity loss. Report by the World Wildlife Fund. https://livingplanet.panda.org/en-US/about-the-living-planet-report

$\mathrm{Xu}, \mathrm{Y}$. and V. Ramanathan. 2017. Well below $2^{\circ} \mathrm{C}$ : mitigation strategies for avoiding dangerous to catastrophic climate changes. Proceedings of the National Academy of Sciences 114(39): 10315-10323.

Yates, L. 2015. Rethinking prefiguration: alternatives, micropolitics and goals in social movements. Social Movement Studies 14(1): 1-21.

Zhao, D. 2010. Theorizing the role of culture in social movements: Illustrated by protests and contentions in modern China. Social Movement Studies 9(1): 33-50. 